\title{
Getting ready for Cincinnati dining
}

\author{
By Deborah Harmeling \\ Library Director \\ Athenaeum of Ohio
}

\section{A survey of attitudes (or preferences) of academic librarians toward restaurants in the greater Cincinnati}

area.

his article is a summary of a survey of dining preferences of librarians in the Greater Cincinnati area. This summary is designed to get your gastric juices ready for Cincinnati in 1989 and to complement the ACRL dining guide being prepared for your use at the April ACRL Convention. Bring it with you and be prepared to make hard decisions about food in Cincinnati!

\section{Background}

Since March 1988, a group of five academic librarians (Deborah Harmeling, The Athenaeum of Ohio; Paula Warnken, Vicki Young, Xavier University; Emily Werrell, Northern Kentucky University; and Kathleen Tiller, University of Dayton) have been meeting at least monthly to prepare a dining guide for ACRL in Cincinnati. Co-workers report that these five people seem to have developed an overwhelming compulsion to talk about food and restaurants. They undertook this difficult task ("Few cities of this size have a better mix of restaurants"1) without benefit of expenditures to do extensive testing. Using their own experiences and formal and informal reviews, they hope to produce a dining guide that will enable conference attendees to choose among the many fine culinary experi-

\footnotetext{
${ }^{1}$ Lydia Chavez, "What's doing in Cincinnati," New York Times, September 11, 1988, p.10.
}

ences Cincinnati has to offer. But they were concerned about the lack of empirical data to confirm their choices. In a recent survey, ${ }^{2}$ Cincinnati ranked ninth in the nation for the number of restaurants listed in the Mobile Dining Guide ( 45 restaurants and a total of 106 stars). With that type of data available, the committee thought it would be advantageous for visiting librarians to know where their local colleagues go to feed the body in Cincinnati. This article is a summary of a survey undertaken among academic librarians in the Greater Cincinnati area, and the committee recommends that its data be used in conjunction with the $A C R L$ Conference Dining Guide which will be available at the Convention.

\section{Methodology}

The survey committee sent out 165 surveys to librarians and staff members in 13 academic libraries on both sides of the Ohio River; 42 surveys were returned. To provide the survey with statistical validity and to make it more complicated, respondents were asked to classify themselves as members of administration, public services, or technical services. We hoped to be able to provide readers with information about the preferences of

\footnotetext{
${ }^{2}$ Linda Parker, "Cincinnati ranks high for taste," Cincinnati Post, January 14, 1988, p.1A.
} 
librarians in each of these categories. Respondents were asked to indicate their favorite restaurants or dining places in 19 categories. Three categories had sub-categories. Respondents were given the opportunity to comment on their choices. Not every respondent answered every question, and one returned a survey with "none" written in every category! His comment indicated that he didn't get out much, and we hope that if you run into him at the convention, you'll invite him to go out to dinner with you.

\section{Results}

Contrary to our expectations, it was difficult to draw any clear-cut conclusions about the preferences of librarians according to types of jobs-e.g., library administrators, technical services, public services. Frankly, we had expected library administrators to gravitate toward the classier, higherpriced restaurants; public services librarians to flock toward the brightly lit, flashy, trendy establishments; and technical services librarians to prefer the quiet, out-of-the-way places. One library administrator recommended Covington Chili in downtown Covington with the glowing recommendation that it has "booths, individual juke boxes, Cokes in bottles, 'real' hamburgers, and waitresses that never write your order down." Two public services librarians praised the elegant, expensive Newport Beach, the newest Comisar gift to palates in the Greater Cincinnati area, and the equally elegant Celestial with its super view of the city. And a technical services librarian raved about the Blue Wisp's great jazz band on Wednesdays at 10:00 p.m.I So do stereotypes bite the dust!

The 42 respondents mentioned 162 eateries; many were found in multiple categories. The Grand Finale was the grand winner, mentioned 35 times! It was especially recommended for dessert and Sunday brunch. Graeter's Ice Cream Parlors came in second, mentioned 25 times. The Maisonette was counted as a favorite 19 times, followed by the Celestial with a score of 18 , Skyline Chili 14 , Crockett's 13, the Precinct 11, and Mike Fink's 10. An eclectic bunch, these librarians! See the accompanying Cincinnati quiche chart for a graphic representation of these statistics.

With 162 favorites, it is impossible to mention all of them in this short article. Members of the committee will be available at the convention with a listing should anyone wish to do a further study of these librarians' preferences. For the purpose of this article we will just present the high favorites in each category.

Favorite restaurant for fancy or special occasions-downtown: The Mobile Guide fivestarred Maisonette was the high favorite in this category, followed by the Mobile Guide four-starred Pigall's. Orchids at the Palm Court located in the Omni Netherland Plaza Hotel was the third favor- ite. Be prepared to spend time and money at all three. The Maisonette and Pigall's feature fine French food; Orchids specializes in contemporary American cuisine.

Favorite restaurant for fancy or special occasions-not downtown: The Grand Finale and the Golden Lamb tied for first place in this category, followed by Heritage and Montgomery Inn. You will need a car to get to any of these places. The Grand Finale is known for crepes and desserts, the Golden Lamb for its historical atmosphere and traditional style food, the Heritage for its use of fresh herbs and Cajun, Southwestern, and regional American specialties, and the Montgomery Inn for sweet, moist barbecued ribs.

Favorite all around restaurant-downtown: Arnold's Bar and Grill was the most popular, followed by Mullane's Parkside Cafe and the Diner on Sycamore. Arnold's combines an historical tavern with up-to-date, lively food and a social ambience. Mullane's features interesting food (many vegetarian entrees) at low prices with little ambience. The Diner on Sycamore is a transported 1950s diner blended with 1980s high tech and an extroverted menu and ambience.

Favorite all around restaurant-not downtown: The Grand Finale was again the highest favored, followed by Germano's, Lenhardt's, and Coach and Four. Germano's (about 15 miles from downtown) is a favorite of one of the committee members. Lenhardt's specializes in German and Hungarian cuisines (its potato pancakes are legendary). The Coach and Four (across the river in Covington, Kentucky) offers a cozy, comfortable atmosphere with imaginative entrees.

Favorite river restaurant: Mike Fink's was the favorite, followed closely by Crockett's and The Waterfront. Mike Fink's is operated by the Bernsteins, a family that has contributed much to Cincinnati's fine dining. Crockett's is actually two floating restaurants - the downstairs River Cafe is more formal and offers an American menu; the upstairs Crockett's is more casual with a raw bar. The Waterfront is actually a complex that houses a restaurant, a nightclub and an open air barge. All three establishments are on the Kentucky side of the river and offer a spectacular view of the city.

Favorite restaurant with a view: The Celestial came in first, followed by the Quality Inn Riverview and the Sovereign. The Celestial with its view from the Eastern hills is elegant, with a FrenchAmerican menu. The Quality Inn Riverview Revolving Restaurant offers a changing view from the Kentucky side of the river. The Sovereign (which has this writer's favorite view) perches on the western side of the city. You do pay for the view.

Favorite restaurant for steaks: The Precinct was the top choice, followed by F \& N Steakhouse and La Normandie. A review of the Precinct in Cincinnati Magazine said, "If steak were a religion, this 


\section{CINCINNATI QUICHE CHART}
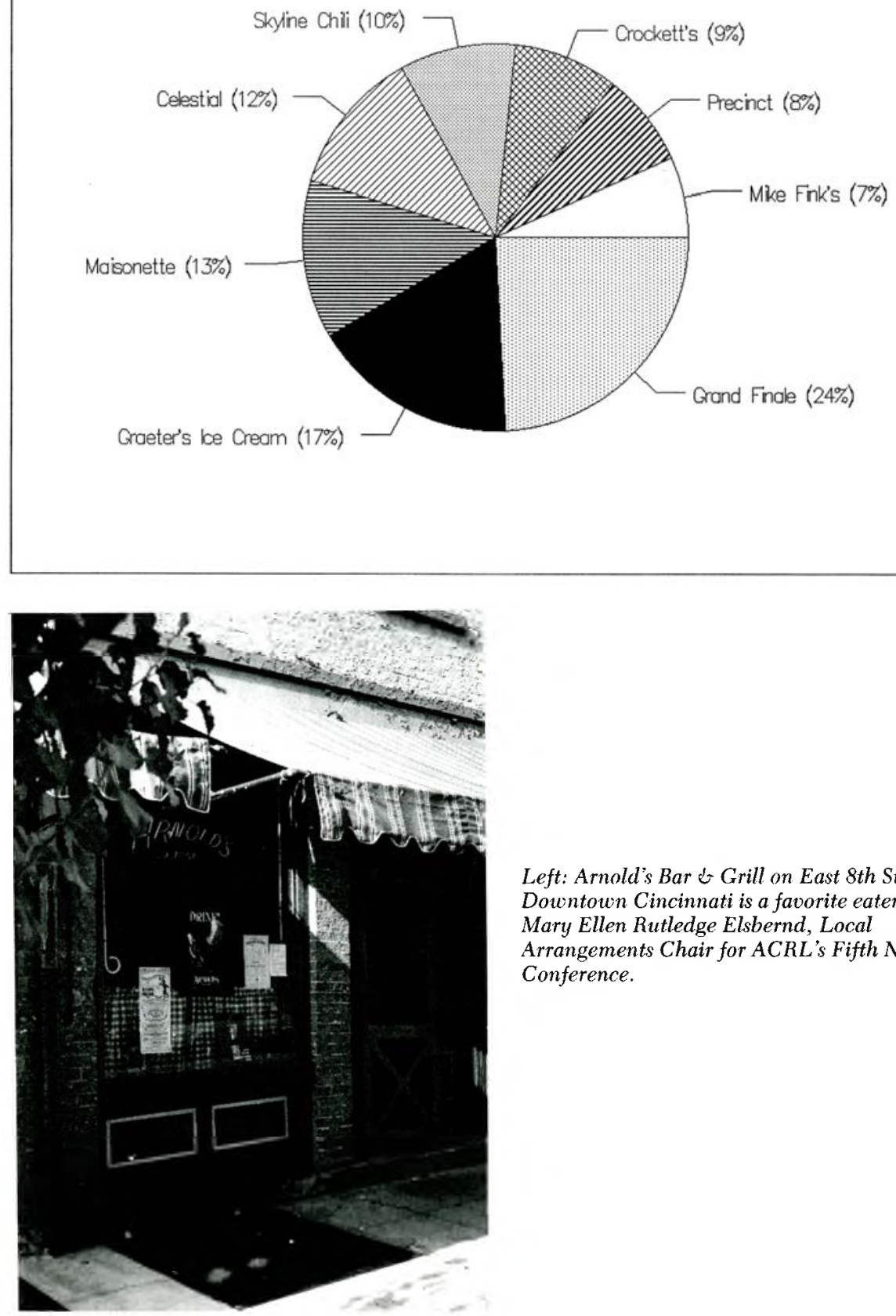

Left: Arnold's Bar \& Grill on East 8th Street in Downtown Cincinnati is a favorite eatery of Mary Ellen Rutledge Elsbernd, Local Arrangements Chair for ACRL's Fifth National Conference. 
would be its cathedral," F \& N Steakhouse is located on Rt. 8 in northern Kentucky along the river. Ask a native how to get there. La Normandie (within walking distance of Convention Center) has as its motto "Dedicated to the Sheer Joy of Eating \& Drinking."

Favorite restaurant for seafood: J's Fresh Seafood Restaurant, Dockside VI, Mike Fink's, and Charley's Oyster Bar \& Grill. J's is one of Cincinnati's most popular fresh seafood restaurants. Dockside VI (in beautiful downtown Norwoodlocal jokel) is located in the Quality Inn in Norwood. Charley's Oyster Bar \& Grill (about 10 miles from downtown) has served fresh seafood to Cincinnati for 12 years.

Favorite Chinese restaurant: Cincinnati abounds in good Chinese restaurants. The preferences of the respondents were (in order): China Gourmet, Blue Gibbon, House of Hunan, Szechuan Gardens, Oriental Wok, and China Kitchen. The committee, along with every food critic in the area, highly recommends the China Gourmet.

Favorite ethnic restaurant-downtown: Scotti's (Italian), House of Hunan (Chinese), Izzy's (Deli?), and Yum Yum (Chinese) were the only clearly downtown contenders. The atmosphere at Scotti's is casual and family-like and Mama Scotti may tell you what to order. We're not sure how a deli qualifies as ethnic but Izzy's is sometimes another world. The original Izzy's on Elm Street is the more interesting experience. The Yum Yum is a small Chinese mom and pop operation with spicy specialties.

Favorite ethnic restaurant-not downtown: Mayura (Indian), El Coyote (Mexican), Lenhardt's (German-Hungarian), Tandoor (Indian), and Old Country Restaurant (Middle Eastern) were the favorite choices.

Favorite restaurant for Sunday brunch: The Grand Finale scored again, followed by the Exemplar Mariemont Inn, Josh's, and the Quality Inn Riverview. If you're in town for Sunday brunch, all are fine.

Favorite restaurant for dessert: The Grand Finale followed by Peterson's and Graeter's.

Favorite mom and pop restaurant: Scotti's was the favorite, followed by Izzy's and Twin Trolley.

Favorite restaurant with a creative menu: $\mathrm{Al}$ pha, followed by Mullane's, Cristos \& Drivakis, and the Bistro on Vine. Alpha offers any kind of omelet you can imagine and lots of vegetarian entrees. Cristos \& Drivakis is out of business at the time of writing this article, but rumor has it that it may come back. The Bistro on Vine offers outstanding desserts and fascinating taste combinations.

Favorite family restaurant: Uno's (Chicago-style pizza), Rockwood Pottery, and Bill Knapps were the favorites. Rockwood Pottery offers great hamburgers, salads, light entrees, and a sundae bar in an old pottery kiln. The Old Spaghetti Factory is also good.

Favorite chili parlor: ${ }^{3}$ Skyline's was the chili of choice, followed by Gold Star, Dixie Chili, and Camp Washington.

Favorite place for ice cream: Graeter's was the overwhelming favorite, followed by Aglamesi's and St. Moritz.

Favorite restaurant for good food and good entertainment: Dee Felice's (jazz and Cajun-style food), followed by Forest View Gardens (singing servers from Cincinnati Conservatory of Music and a mini-musical each night) and Coco's (jazz and eclectic food).

Favorite place to get together for drinks: Blind Lemon in Mt. Adams, followed by Arnold's (downtown) and Barleycorn's (downtown and on the Kentucky side of the river).

Favorite place for drinks and dancing: Apparently librarians in Cincinnati don't dance much; few responded to this section. Those who did indicated the Dock, Glass Menagerie, Caddy's, the Waterfront, and the Top of the Crown as their favorites. All of these were public services librarians.

Not to be missed: The Maisonette, Orchids at The Palm Court, Izzy's.

\section{Conclusion}

Based upon an admittedly small sample, the committee feels justified in presenting these survey results to those who plan to attend the ACRL Conference in Cincinnati in April 1989. Together with the ACRL Conference Dining Guide, this survey should have enough variety and choices of eating establishments to get you through the convention without losing weight.

\section{Areas for further research}

The committee also feels that this survey was not as complete as it could have been and that further research is not only indicated but imperative. We would like to invite you to join us as we continue our efforts to do a definitive study on the preferences of academic librarians toward restaurants in the Greater Cincinnati area. The ACRL Convention will provide a unique opportunity to add a broader sample of academic librarians to our survey base. To facilitate continuing research in this area, the Dining Guide committee hopes to set up a Colleague Dinner Companion Program, (CDC, not to be confused with CD ROM). Through this program, local librarians will be available to provide transportation for 2 to 4 colleagues to their favorite restaurant. They will also provide compan-

${ }^{3}$ For more information concerning the phenomenon called Cincinnati chili, see Mary Ellen Rutledge Elsbernd, "Trivial Matters, Cincinnati style," College \& Research Libraries News 49 (December 1988): 782 . 
ionship and perhaps witty conversation during the meal. Check every day at the Hospitality Booth for the evening's possible selections and sign up by 4:00 p.m. In this way, we hope to provide you with every opportunity to sample the joys of eating in Cincinnati and to participate in research that makes a differencel Bon appetit!
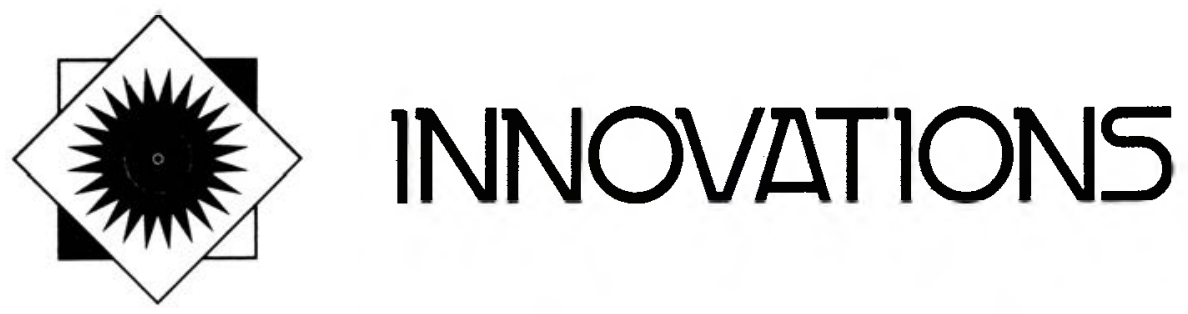

\title{
Automation orientation programs at the University of Delaware Library
}

\author{
By Carol Anne Hert \\ Senior Assistant Librarian, Systems Department \\ University of Delaware
}

Integrated online library systems (IOLS) are changing the way libraries function and how they are organized. As systems are implemented, new types of work are being created and old barriers between units are falling. Critical to the successful implementation of an integrated system is an enthusiastic staff: one not threatened by change, and able to think beyond the boundaries of current jobs to creatively assess automation's role in their work. ${ }^{1}$

The creation of this kind of spirit requires more than task-oriented training, although that is certainly an essential element of any training program. Sokol and Bulyk have outlined a three-part model of training to enable the successful implementation of new technology. ${ }^{2}$ The components are: sensitization, education, and training. Sensitization refers to training to provide the emotional preparation for new technology. It should address concerns about change such as loss of control and job security, and should build staff's confidence about their ability to master the system. Education

\footnotetext{
${ }^{1}$ Sheila D. Creth, Effective On-the-Job Training: Developing Library Human Resources (Chicago: American Library Association, 1986), 2.

Ellen W. Sokol and John C. Bulyk, "The Truth About Training," Journal of Information Systems Management 2 (Fall 1985): 75-76.
}

is the process of teaching staff to think creatively about a particular technology's possibilities and implications within the context of institutional missions. Actual task-related training to provide staff with the necessary proficiencies to employ the new technology is the final component of the Sokol and Bulyk model.

At the University of Delaware Library, the Systems Department is charged with developing training for our IOLS, NOTIS. Recognizing that taskspecific training alone would not be sufficient for the smooth implementation of the system, we developed a series of orientation programs designed to address the sensitization and education components of Sokol and Butyl's training model. We have merged these two components in our programs in the belief that they can not really be separated. A feedback loop exists, with increasing confidence about the system making education about the capabilities and potentials of the system easier, and vice versa.

The University of Delaware Library Systems Department's orientation programs are of two types: programs to teach basic system competencies, and programs focusing on general automation and system topics. Basic competency programs include introductions to the public catalog and to the technical services mode of the system. Among the 